IFN Working Paper No. 830, 2010

\title{
The Interaction of Entrepreneurship and Institutions
}

Magnus Henrekson and Tino Sanandaji 


\title{
The Interaction of Entrepreneurship and Institutions
}

\author{
Magnus Henrekson ${ }^{1}$ and Tino Sanandaji ${ }^{1,2}$
}

April 15, 2010

\begin{abstract}
Previous research, notably Baumol (1990), has highlighted the role of institutions in channeling entrepreneurial supply into productive, unproductive or destructive activities. However, entrepreneurship is not only influenced by institutionsentrepreneurs often help shape institutions themselves. The bilateral causal relation between entrepreneurs and institutions is examined in this paper. Entrepreneurs affect institutions in at least three ways. Entrepreneurship abiding by existing institutions is occasionally disruptive enough to challenge the foundations of prevailing institutions. Entrepreneurs sometimes have the opportunity to evade institutions, which tends to undermine the effectiveness of the institutions, or cause institutions to change for the better. Lastly, entrepreneurs can directly alter institutions through innovative political entrepreneurship. Like business entrepreneurship, innovative political activity may be productive or unproductive, depending on the incentives facing entrepreneurs.
\end{abstract}

JEL Codes: L5; M13; O31; P14.

Keywords: Entrepreneurship; Innovation; Institutions; Regulation; Self-employment.

\author{
Research Institute of Industrial \\ Economics (IFN) \\ Box 55665 \\ SE-102 15 Stockholm \\ Phone: +46-8-665 4500 \\ Fax: +46-8-665 4599 \\ e-mail: magnus.henrekson@ifn.se
}

\author{
${ }^{2}$ Harris School of Public Policy \\ University of Chicago \\ 1155 East $60^{\text {th }}$ Street \\ 60637 Chicago IL
}

$\underline{\text { tino@uchicago.edu }}$

\footnotetext{
* This paper builds on work that originally included Robin Douhan as a key contributor. Robin unexpectedly and tragically passed away on 10 August 2009. His death, at the age of 31, was caused by sudden heart failure. His friendship, kindness and talent are deeply missed. Our profound intellectual debt to Robin is hereby acknowleged. Financial support from the Jan Wallander and Tom Hedelius Research Foundation and from the Gustaf Douglas Research Program on Entrepreneurship at IFN is gratefully acknowledged. We are grateful for useful comments and suggestions on earlier versions of this paper from Johan Almenberg, William Baumol, Selva Baziki, Niclas Berggren, Pete Boettke, Dan Johansson, Linda Nyberg and two anonymous referees.
} 


\section{Introduction}

It has been recognized for some time that institutions shape the actions of entrepreneurs (e.g., Parker, 2004, ch. 3). Yet Baumol's seminal work (1990) contributed to the literature by showing that institutions determine not only the level, but also the type of entrepreneurship. Individuals put their entrepreneurial talent to use in activities that are productive, unproductive or destructive. The institutional setup or "the rules of the game" dictate relative return, and hence the allocation across these activities. However, institutions do not merely control entrepreneurs, entrepreneurs control them-through business activity, evasive methods and political entrepreneurship. This paper will explore both sides of this interaction: how the institutional framework influences entrepreneurship and how entrepreneurs in turn influence the emergence and evolution of institutions.

An influential stream of research has built on the insight that productive abilities can also be used for rent-extracting purposes (e.g., Murphy, Shleifer and Vishny 1991, and Acemoglu 1995). This literature typically stresses that institutions determine the relative rates of return of productive and unproductive types of activities. This relationship has typically been assumed to be unilateral, running from institutions to entrepreneurship, while a potential reverse or bilateral causality has been largely neglected. ${ }^{1}$

Yet entrepreneurship does interact with institutions within the course of a bilateral relationship. This possibility has been touched upon previously in the public choice school. Buchanan (1980, p. 14) noted:

Faced with a prospect of differentially unfavorable tax treatment by government, a person or a group may (1) engage in lobbying effort; (2) engage directly in politics to secure access to decision-making power, and/or (3) make plans to shift into or out of the affected activity.

In general terms, Buchanan concludes that entrepreneurs affect institutions by: (i) market innovations that alter institutions or the effect of institutions; (ii) evasion of institutions; and (iii) direct political entrepreneurship.

\footnotetext{
${ }^{1}$ Boettke and Coyne (2009) thoroughly analyze the link between institutions and entrepreneurship (and also offer a comprehensive review of the related literature). Boettke and Coyne (2003) probably contains the strongest assertion that institutions are the ultimate cause of growth, whereas entrepreneurship is merely a proximate cause, since according to them its supply and direction is fully determined by the institutional setup.
} 


\section{Entrepreneurship Defined and Categorized}

\subsection{Entrepreneurial Talent}

In line with Baumol (1990) and Murphy et al. (1991), an entrepreneur is defined here according to a set of talents. There is no consensus in the literature regarding the nature of these talents; some scholars emphasize cognitive abilities while others point to motivation (preferences). ${ }^{2}$ We define entrepreneurial talent as a combination of perceptiveness, the ability to detect opportunities, and the capability of undertaking new ventures in response. The definition thus includes both motivation and ability. Profitable business projects, the chance to appropriate or earn rents and the possibility to affect policy constitute the opportunities explored here.

Self-employment and start-ups embody the most typical forms of business entrepreneurship. Our definition of entrepreneurship precludes many forms of self-employment, however. Most importantly, self-employment that is not innovative in nature does not qualify as entrepreneurship. In reality, no clear boundary delineating truly innovative entrepreneurship from non-innovative self-employment can be drawn; as a result, we employ a continuum of selfemployment activity organized from purely non-innovative to highly dynamic entrepreneurship.

The idea that innovative individuals contribute to institutional change has a long history in political science. In his case study of political power in New Haven, Dahl (1961) introduced the term "political entrepreneurs," individuals who recombine resources in the policy arena to bring about change. The political arena in New Haven was entrepreneurial in its alertness to "citizen desires" and "the ease with which the political stratum can be penetrated" (Dahl 1961, p. 93) by new individuals. In accordance with political scientists, we also call entrepreneurship undertaken with the direct aim of altering institutions political entrepreneurship. ${ }^{3}$

\footnotetext{
${ }^{2}$ Research on typical entrepreneurial properties focus on two major themes: cognitive abilities and motivation. The model entrepreneur is someone who is alert to opportunities. Cognitively, this amounts to efficiently structuring abundant information in order to make feasible judgments (Gaglio and Katz, 2001). It also involves a capacity to think in novel ways (Ward, 2004). In regard to motives, the longest standing characterization of an entrepreneur is associated with the need to achieve and create (Weber, 2001[1905]; McClelland, 1961). Furthermore, an entrepreneur exhibits a willingness to take calculated (but not necessarily calculable) risks. Knight (1921) claims that the ability to cope with uncertainty is the main function of entrepreneurship. For a survey of empirical evidence on these motivational aspects, see Rausch and Frese (2000). These properties are consistent with the historical accounts in Schumpeter (1934) and Kirzner (1973, 1992).

${ }^{3}$ Van der Steen and Groenewegen (2009) distinguish between political entrepreneurship, institutional entrepreneurship and policy entrepreneurship. In order to avoid an overabundance of definitions, we use political, institutional and policy entrepreneurship interchangeably.
} 
The term business or market entrepreneur is used here, somewhat loosely, to refer to traditional Schumpeterian entrepreneurs, distinct from political entrepreneurs. Similar to business entrepreneurs, political entrepreneurs are people who are alert to opportunities, bear risk, reorganize coalitions and resources, and ultimately bring about innovation, be it socially positive or negative.

Despite clear differences in undertakings and goals, business and policy entrepreneurs enjoy similar functions. Law-abiding business entrepreneurs and institution-altering political entrepreneurs both discover and meet unfulfilled needs, and both must bear the personal risk associated with their ventures. Lastly, all entrepreneurs need to coordinate and reorganize the resources needed to undertake change, be it capital, labor or political alliances. In light of these parallel functions, it is likely that all types of entrepreneurs share at least some individual characteristics.

Lee Kuan Yew, Robert Mugabe and Silvio Berlusconi are some of the major political entrepreneurs discussed here. While they are quite obvious examples, Lee, Mugabe and Berlusconi only form the tip of the iceberg of political entrepreneurship. Innovative political activity occurs constantly on all levels of government. Similar to business entrepreneurship, the most iconic figures become national heroes, although most political entrepreneurship is local and small-scale. Societal factors such as demographic change and technological development drive the need for such activity. For example, the expansion of a suburb entails new roads and public services, and the individual who identifies and responds to this need is the political entrepreneur. Schneider et al. (1995) focus on community entrepreneurs, who organize to provide local public goods. They find that thirty percent of city clerks in suburban American counties could identify an individual in their community whose "policy proposals and political position represented a dynamic change from existing procedures". Again, akin to business entrepreneurs, entrepreneurial individuals often start out as small-scale local political entrepreneurs who expand the scope of their activity if successful. Current U.S. president Barack Obama famously started his political career as a "community organizer" in Chicago.

Of course, all political leaders share some entrepreneurial aspects. Virtually all of them change statutes, introduce new legislation, or carry through reforms at some point during their careers. One would be hard-pressed to find any long-serving politician who has not contributed to at least some minor institutional change. Does that mean that all politicians are polit- 
ical entrepreneurs then? Not necessarily; policy entrepreneurship is not alone in suffering from this problem of delineation. Almost every firm or public institution engages in some degree of innovation and alertness in its day-to-day activities. All economic activity involves a minimum degree of entrepreneurship, regardless of how entrepreneurship is defined (Kirzner 2009). Economic entrepreneurship — whether explicit or implicit—can be seen as a matter of degree. Changing the color of a product is not enough; an activity must be sufficiently innovative for it to be defined as entrepreneurial and made distinct from non-entrepreneurial activity. The same is true for political entrepreneurship; institutional reform has to be sufficiently novel for it to qualify as policy entrepreneurship. Where one chooses to draw the line depends on context and the researcher's own judgment.

\subsection{Institutional Entrepreneurs in Sociology}

The fundamental concept of institutional entrepreneurship in sociological literature is the same as the one discussed here, although its framing and perspective are different (Scott 2004). In this rich literature, institutions appear as deeper and firmer aspects of social structures. Scott writes, for example, that (1995, p. 33) "institutions are social structures that have attained a high degree of resilience. [They] are composed of cultural-cognitive, normative, and regulative elements that, together with associated activities and resources, provide stability and meaning to social life." Institutional entrepreneurship can "account for institutional change endogenously" (Battilana 2006). DiMaggio (1988) ${ }^{4}$ introduced this function to explain how individuals can bring about radical change not necessarily in line with prevailing institutions.

Prior to DiMaggio, prevailing sociological theory could only explain institutional change in terms of isomorphism (organizations spreading their rules of behavior); it had difficulty accounting for situations in which dramatic change takes place in the opposite direction of initial institutional inertia, such as a rapid shift in the market structure or the fact of a mature firm suddenly changing its core business and strategy. Other types of discontinuous change also represented something of a puzzle to this theory. "How can organizations or individuals innovate if their beliefs and actions are all determined by the very instructional environment they wish to change?" (Battilana 2006, p. 654). The paradox is to some extent resolved by

\footnotetext{
${ }^{4}$ Rather, this constitutes one school of entrepreneurship in sociology. For a seminal sociological treatment of market entrepreneurship, see Swedberg (2000). Hwang and Powell (2005) survey the neoinstitutional literature on institutional entrepreneurship.
} 
introducing the entrepreneur. This allows for the capacity of agents to "make a difference," acting sometimes contrary to what the prevailing institutional structure would predict, and even change these prevailing institutions.

The sociological perspective that builds on DiMaggio's institutional entrepreneur coincides in part with the economic and political science definition of institutions, namely informal institutions such as norms and culture. Discontinuous change of institutions through individual actions fits well with the idea of political entrepreneurs altering institutions. The sociological view of structures and institutions, which is reinforced every time individuals act in line with them, resembles most economists' definition of habits and hardwired preferences (Becker and Murphy 2000).

In contrast to sociologists, economists fail to see a paradox in the fact of entrepreneurs being influenced by institutions at the same time as they contribute to institutional change and evolution. Nor do economists recognize agents being "trapped" in institutions, requiring entrepreneurs to escape. This reflects sociologists' much broader definition of institutions and structures, including most beliefs and preferences. (Sociologists view these institutions as stronger and more binding, and comparatively more important than economic incentives or relative prices.) Ultimately, this difference in perspective mirrors the classical disagreement between sociologists and economists regarding the extent individuals are free to make choices and control their own circumstances. Nevertheless, since sociologists allow for entrepreneurs to escape their structural bonds while economists emphasize the role of broad institutions and social context in forming individual choice in this area, the two disciplines are closer to each other regarding institutional entrepreneurship than on many other issues.

\subsection{Entrepreneurship - A Typology}

In our analysis, we follow Baumol's lead (1990) in distinguishing between productive and unproductive/destructive entrepreneurship. ${ }^{5}$ Due to differences in focus, however, we do not discriminate between destructive and merely unproductive entrepreneurship, choosing rather to merge the two categories. Our attention is directed rather at entrepreneurs' response to institutions. Entrepreneurs can abide by institutions, and later even evade institutions. Finally

\footnotetext{
${ }^{5}$ Sobel (2008) finds empirical support for Baumol's theory. Unproductive entrepreneurship is effort spent on the redistribution of wealth rather than the creation of additional wealth, whereas destructive entrepreneurship is not only redistributive but also reduces total wealth.
} 
we include the possibility for entrepreneurs to alter institutions. This creates a 2 x 3 matrix, where each entrepreneurial activity can be assigned to one of the six types.

Baumol (1990) introduces his analysis as an extension of Schumpeter's (1934) theory of innovations as new combinations, particularly when discussing productive entrepreneurship. ${ }^{6}$ Innovative entrepreneurship may be, and often is, incremental in nature, progressing in small steps over long periods. The same is true for political entrepreneurship.

Unproductive/destructive entrepreneurship, on the other hand, entails some combination of rent-seeking technologies that enables the entrepreneur to appropriate rents from other agents. In this process, the social product may be unaffected, as in the case of a simple transfer, or be lowered, as in the case of destructive entrepreneurship. In the terminology of the neoclassical theory of the firm, the distinction between the different types can be characterized as a shift inward (destructive) or outward (productive) of the production possibility frontier (Coyne and Leeson 2004).

Given the definition of the entrepreneur, it simply cannot be assumed that entrepreneurs passively respond to institutions. Indeed, theories within the school of new institutional economics usually describe the entrepreneur as a key agent in institutional change. North (1990), for instance, holds that the entrepreneur acts on the fringe of a given institutional setup and is the agent that embodies dynamism and change, all occurring in a setting in which agents' behavior is otherwise determined by institutions. This is broadly consistent with the framework presented here. A second dimension of our typology distinguishes behavior within the constraints of the institutions from behavior aimed at evading these constraints. Evasive entrepreneurship is defined as an activity aimed at circumventing the institutional framework. Finally, entrepreneurs may actively alter institutions through political activity. These definitions are illustrated in Figure $1^{7}$

\footnotetext{
${ }^{6}$ Productive business entrepreneurship can entail: (i) introduction of a new good (or a new quality of a good); (ii) introduction of a new method of production; (iii) opening of a new market; (iv) conquest of a new source of supply of raw materials or semi-manufactured goods; or (v) implementation of a new organizational form. One can summarize these points as new combinations of resources and technology on the market that create positive social value.

${ }^{7}$ As will be discussed, both abiding and evading entrepreneurship can have the unintentional result of changing institutions. Altering entrepreneurship differs in that it is direct, and more importantly, that the aim is to change institutions.
} 
The allocation of entrepreneurship between abiding, evading and altering institutions is influenced by the relative payoff of those activities, much like the allocation between productive and unproductive/destructive entrepreneurship (Baumol 1990). It is important to keep the vertical distinctions in Figure 1 (from productive to unproductive/destructive) separate from the horizontal ones (choosing to follow a career as an abiding business entrepreneur, an evasive [legal or illegal] entrepreneur or an altering political entrepreneur).

\begin{tabular}{|c|c|c|c|}
\hline ABIDE & EVADE & ALTER \\
\hline PRODUCTIVE & $\begin{array}{c}\text { Pursue a business } \\
\text { opportunity within pre- } \\
\text { vailing institutions. }\end{array}$ & $\begin{array}{c}\text { Sidestep stifling labor } \\
\text { market regulations } \\
\text { through a new } \\
\text { contractual form. }\end{array}$ & $\begin{array}{c}\text { Provide a new local } \\
\text { public good, private } \\
\text { security firms. }\end{array}$ \\
\hline $\begin{array}{c}\text { UNPRODUCTIVE/ } \\
\text { DESTRUCTIVE }\end{array}$ & $\begin{array}{c}\text { Sue competitors for a } \\
\text { share of their profit. } \\
\text { Rogue states; rivalry } \\
\text { between warlords. }\end{array}$ & $\begin{array}{c}\text { Bribe a government } \\
\text { official to obtain a con- } \\
\text { tract. Illegal syndicates. }\end{array}$ & $\begin{array}{c}\text { Lobby for a new regula- } \\
\text { tion to protect an indus- } \\
\text { try. Repeal property } \\
\text { rights to plunder a } \\
\text { wealthy group. }\end{array}$ \\
\hline
\end{tabular}

Figure 1. A Typology of Entrepreneurship and Some Illustrative Examples.

Baumol only discusses business entrepreneurs as productive entrepreneurship, whereas other entrepreneurial activities (such as joining the bureaucracy) are discussed solely in unproductive terms. In our categorization, both institution-abiding business entrepreneurship and institution-altering political entrepreneurship can be productive. Even evasive entrepreneurship can be productive, both directly (by evading institutions that hamper production) and indirectly (by forcing a change in such institutions). This is not based in a disagreement with Baumol; rather, it merely arises from our including two categories - evading and altering entrepreneurship - that he did not. ${ }^{8}$

In practice, however, not all activity can be neatly categorized by our definitions. Entrepreneurship may incorporate aspects of evasion and alteration at the same time, for example, such as the organization of boycotts and passive resistance in order to change a law. The ma-

\footnotetext{
${ }^{8}$ Baumol (1990) focused mainly on the allocation of entrepreneurial talent, rather than the supply of entrepreneurship (although he did not rule out the possibility that the supply of entrepreneurship could also be affected). We believe institutions can strongly affect the total supply of entrepreneurship, as will be exemplified below. In Henrekson and Sanandaji (2010), for example, we discuss how institutions governing taxation affect the supply of entrepreneurial effort. See also Asoni and Sanandaji (2009).
} 
trix aims solely to give some structure to the discussion, and does not claim perfect and mutually exclusive categorization.

Finally, it should be noted that institutions that direct talent to different activities do not necessarily affect exactly the same individuals. If the rules of the game in a country change in favor of business entrepreneurship, a successful influence peddler does not automatically become an industrialist. Rather, when an individual drops out of political entrepreneurship, room is made for another individual with abilities suited for building productive firms.

\section{Entrepreneurship Across Different Activities}

\subsection{The Politico-Economic Approach}

Bilateral causal effects between politics, institutions and economic performance have long captured the interest of economists. Baumol (1990) asserts that institutions determine "the social structure of payoffs", which govern the conduct of economic activity. Institutions have moved to the fore of mainstream explanations for economic performance, especially over the long term; see, for example, North and Weingast (1989), Rodrik et al. (2004), and Acemoglu et al. (2005). On the macro level, some studies empirically identify the effects of economic performance on political institutions (e.g., La Porta et al. 1999, and Chong and Calderón 2000).

Certain economic institutions possess particular importance for entrepreneurship, including property rights, tax codes, social insurance systems, labor market legislation, competition policy, trade policies, capital market regulation, enforcement of contracts, and law and order (Hall and Jones 1999). A constitution is a prime example of an economically significant political institution because of its implications for voting systems, for example, and directives controlling a country's degree of centralization and federalism (Persson and Tabellini 2004, 2006). Institutions are both formal and informal, and can in both cases be affected by entrepreneurs. ${ }^{9}$ It is much easier to alter formal institutions through political activity than change informal rules such as norms, values and codes of conduct.

\footnotetext{
${ }^{9}$ For an in-depth discussion of formal and informal institutions and how they pertain to entrepreneurship, see Boettke and Coyne (2009).
} 


\subsection{Abiding Entrepreneurship}

The abiding market entrepreneur is the archetypical entrepreneur, the one most discussed in the literature. Productive business entrepreneurship increases an economy's degree of innovation and its ability to adapt to exogenous conditions. Innovativeness forms the core of Schumpeter's (1934) entrepreneur who disturbs the existing equilibrium, whereas Kirzner's (1973, 1992) entrepreneur is marked by the ability to adapt. ${ }^{10}$ While productive entrepreneurship is important in all economies, the need for adaptation and innovativeness depends on the external environment. For instance, in times of rapid change, driven for example by a high rate of technological progress or new supplies of resources, adaptability becomes paramount. ${ }^{11}$

The relationship between abiding entrepreneurship and the evolution of institutions is complex. On the one hand, truly innovative entrepreneurship can create so much change that the foundation of the current institutional structure is challenged. Truly disruptive entrepreneurship, such as the successful introduction of a revolutionary new technology, can lead to the reform and dissolution of extant institutions, notably in traditional societies. Technological progress can also alter the effect of institutions; one salient and recent example is the impact of the Internet on intellectual property rights.

On the other hand, entrepreneurship can be self-perpetuating. It creates a constituency of consumers, private-sector workers and self-employed who support productive institutions. Technological breakthroughs often offer opportunities for new entrepreneurship, both of the market and political type. No less importantly, productive entrepreneurship legitimates the institutions that foster it by creating demonstrable new wealth, products and jobs. The American economic system, with its high degree of inequality coupled with the opportunity to grow fabulously rich, has maintained its legitimacy largely because entrepreneurs from Andrew Carnegie to Bill Gates have created new value that has benefited the general public (Acs and Phillips 2002)). Furthermore, entrepreneurs (and non-entrepreneurs) abiding by institutions tend to strengthen these very institutions. This is particularly important for informal institutions, such as codes of conduct and traditions, which are reinforced each time they are ac-

\footnotetext{
${ }^{10}$ See Baumol (2010), Holcombe (2007) and Yu (2001) for discussions of these two aspects and how they can be combined in the same system. See also Kirzner (2009) for a critical assessment of such merging.

${ }^{11}$ It could be noted that abiding entrepreneurship is not limited to market or business entrepreneurship. The nonprofit sector is a sizable share of the economy in countries such as the United States, and includes a large amount of productive non-market entrepreneurship. Boettke and Coyne (2009) further discuss social entrepreneurship and its relation to institutions. Compared to market entrepreneurship, social entrepreneurship is more likely to be a combination of abiding and altering activity towards institutions.
} 
knowledged and allowed to guide behavior. Regarding more formal institutions it has been noted that the law itself derives much of its value from the respect that it is awarded (Kasper and Streit 1998). Becker and Murphy (2000) use the neoclassical economic framework to argue that institutions are reinforced through abiding behavior. They use the U.S. constitution as an example of an institution whose rules have been strengthened as Americans throughout history have followed its guiding principles. In contrast, similar constitutions in other countries, notably in Latin America, have been weakened over time as each violation of its principles has reduced people's respect for the constitution and tradition.

\subsection{Evasive Entrepreneurship}

In the case of evasive entrepreneurship, the activities of the entrepreneur do not alter the formal institutional set-up but rather the impact of institutions already in place. Imperfections in the institutional framework can be used innovatively to appropriate rents from a third party, exemplified well by the shortcomings in the protection of private property rights. Agents may act on such institutional flaws by outright theft, fraud, litigation or more sophisticated economic crimes. Productive examples include entrepreneurs who pursue contractual arrangements to escape some costly institution. Tax avoidance (legal) and tax evasion (illegal) are typical examples. A business-owning entrepreneur may engage in such evasive entrepreneurship to reduce costs, while other entrepreneurs, notably within tax consultancies and law firms, may found a new business based on an innovation that enables others to circumvent institutional barriers. While illegal and harmful for public finances, tax evasion can be productive if the economic activity in question would not take place without such evasion.

Other, more mundane, instances of this type include the businessman who uses his entrepreneurial talent to trace the right bureaucrat to approach with a bribe. In the simplest case, this constitutes an instance of evasive entrepreneurship. One can think of yet more elaborate situations where the entrepreneur earns money by selling services all while utilizing knowledge of bureaucratic procedures or personal acquaintances. The bureaucrat who receives the bribe can also act entrepreneurially, by increasing the cost of abiding by the institutions, for instance.

Evasive entrepreneurship can be productive or unproductive depending on the circumstances. If a business activity would not have taken place at all without the said circumvention of laws, it may be that the evasive actions are indeed productive. Other times, the evasion of institutions results in a waste of resources (such as costly cross-border smuggling, rather than regu- 
lar bulk import). More obvious examples of destructive evasive entrepreneurship include predatory (innovative) criminal activity.

Evasive behavior by entrepreneurs, including the creation of contracts to overcome institutional impediments, tends to weaken the institutions that are being evaded. A formal institution that is not enforced is likely to lose its practical relevance. The pursuance of new contractual arrangements in order to evade labor regulations provides another example of this process As evasion spreads, regulations lose some of their bite, and may in time be abolished if not modified to deal with evasion attempts.

This race between regulators and innovative evaders is also a defining feature of the financial sector. Destructive evasive entrepreneurship in the sub-prime security market contributed to the 2008 financial crisis as implicit government guarantees were exploited by assuming excessive risk (Calomiris 2009). Evasive entrepreneurship also caused institutions to change in this case, albeit in the other direction — making them more binding and comprehensive.

\subsection{Altering Entrepreneurship}

Baumol (1990) describes productive entrepreneurship solely in terms of private sector business activity. However, other types of entrepreneurship can also be productive. Clearly, not all political activities can be defined as rent seeking; policy innovations often improve welfare, especially in favorable institutional environments. The National Science Foundation, for example, was created in part through political entrepreneurship (Polsby 1984). Good institutions do not arise out of nowhere, and are often the result of policy entrepreneurship by gifted pivotal individuals. The productive political entrepreneur deserves recognition as a fundamental agent in the economy, just like the productive market entrepreneur.

DiLorenzo (1988) emphasizes the unproductive and destructive activities of rent seeking political entrepreneurs, writing that "[t]he essence of political entrepreneurship is to destroy wealth through negative-sum rent-seeking behavior" (p. 66, italics in original). He maintains that ignoring political entrepreneurs has led public choice theorists to underestimate the destructive effects of politics. We conclude in turn that the focus on rent seeking has led to an underestimation of the total dynamic potential embodied in institutional change, both when channeled productively and unproductively/destructively. Both types of activities are carried out in modern developed democracies, sometimes concurrently, often leaving the observer to 
decide whether the policy innovation was productive or destructive (at least as long as the reform does not clearly violate Pareto efficiency). Wagner (1966) argues that political entrepreneurs can substitute for the rent-seeking activities of large interest groups, which mitigates the central difficulties in overcoming collective action problems and organizing interest groups emphasized by Olson (1965).

The incentive structure guides the allocation of political entrepreneurial effort, just as it guides the allocation of business entrepreneurship. All societies enjoy a mix of incentives; political entrepreneurship is allocated to both productive and unproductive/destructive institutional reform efforts, in analogy to other types of entrepreneurship. Baumol's (1990) broader theory of entrepreneurship holds true for political entrepreneurship in particular. While all three types take place in all societies, relative allocation can vary greatly, helping to determine the societies' level of welfare and rate of growth.

The same individual may shift between categories, just as a business entrepreneur may introduce a new product one year, and frivolously sue to bar competition the next. Barack Obama and other community organizers in the urban United States arguably engage in both productive political entrepreneurship (such as easing job searches in their community) and unproductive entrepreneurship (jockeying for city subsidies to their respective constituents, for example). The broader rules of the game are not changed by these activities, even if certain pieces of legislation may change. While most political entrepreneurship does not hold enough clout to fundamentally alter the rules of the game, there are examples of entrepreneurship that change institutions so much that the broader rules guiding other political entrepreneurs shift across categories. Some examples of this, such as Zimbabwe's leader Robert Mugabe, will be given later.

Entrepreneurial activity in the market is governed by a strong feedback mechanism, namely profit and survival. Where institutions are productive, individuals with socially beneficial activities make profits, thereby guiding entrepreneurial talent to inherently productive activities. Market entrepreneurship is particularly beneficial in a social sense as it can allocate resources in an efficient manner using profit and loss as a guide; where institutions are unproductive or destructive, individuals can become rich through activities that redistribute wealth, or that are purely predatory. The feedback mechanism is less powerful for political and institutional entrepreneurship, however (Glaeser 2005). Politicians can hope to be re-elected or 
elected/appointed to higher office, but not all policy entrepreneurs are office holders, and the political reward mechanism is rather noisy. Singapore's national leader Lee Kuan Yew was rewarded for his social reforms with a long tenure, but so were Cuba's Fidel Castro and Zimbabwe's Robert Mugabe. Constructive policy entrepreneurs are more often rewarded for good activity and punished for destructive reforms when the broader institutional setting is propitious. The quality of the meta-institutions includes the norms, values and beliefs of the general public - better informed and more socially oriented voters are more likely to reward socially beneficial reforms (Caplan 2007, Strömberg 2004). Rudolf Giuliani’s tenure as Mayor of New York (1994-2001) elevated him to national prominence, since the public perceived him as having responded to the needs of the city with successful reforms.

Another, perhaps more controversial, conclusion is that market entrepreneurship is more likely to be efficient and productive than policy entrepreneurship, precisely because of the weaker feedback mechanism of the latter. ${ }^{12}$ Although both types of activities can be unproductive when the broader institutional setting is of low quality, weak feedback mechanisms ensure that policy entrepreneurship may not be directed in a productive way even if the metainstitutions are generally favorable. Furthermore, many barriers to political reform exist even in good institutional settings, including the need to mobilize a majority, whereas market innovations enjoy lower barriers to entry.

\section{The Interaction between the Entrepreneur and Institutions}

Changes in institutions should take into account not only the direct response of entrepreneurs, but also the subsequent change of institutions through entrepreneurial feedback. This feedback may be direct or indirect. Indirect feedback occurs when policy makers or political entrepreneurs feel the need to change institutions due to the response of entrepreneurs to institutions within the given framework. Examples of indirect feedback include the effects of evasive entrepreneurship that weaken institutions (or their actual impact), a decline in productive entrepreneurship that forces institutional reform, or an increase in rent-seeking entrepreneurship that reduces the legitimacy of free-market reform.

Direct feedback includes changes in institutions by market entrepreneurs, such as transaction costs or protective technology. Thorstein Veblen argued that technological change results in

\footnotetext{
${ }^{12} \mathrm{We}$ owe this observation to an anonymous referee.
} 
new habits of life and thought, thus giving rise to new institutions (Walker 1977). When technology is introduced by entrepreneurs, this creates a link between entrepreneurship and institutions. ${ }^{13}$ Yet Boettke and Leeson (2009) point to a different way of altering institutions, namely through productive entrepreneurs' "creation of protective technologies that secure citizens' private property rights vis-à-vis one another". These activities are most important in weak institutional environments, such as in many third world countries. Entrepreneurs help improve institutions by creating private protection methods that restrict predation in the absence of a well-functioning government. These include private law and courts, private police protection, bilateral punishment schemes (for example ostracism), reputation mechanisms for multilateral punishment of dishonest conduct, and social norms and customs. An example of this process can be found in the informal, unwritten rules of commercial activity and private courts in tribal units in Africa. Hwang and Powell (2005) consider the creation of standards to guide the activities of organizations - itself a form of institution - as an entrepreneurial act. In his discussion of second-best institutions, Rodrik (2008) points out that Ghanaian firms find courts too costly as a method of contract enforcement. Such firms have relied on selforganized measures of contract enforcement instead, namely relational contracting through personal relationships and repeated interactions.

Political entrepreneurship obviously houses an endogenous component. Productive political entrepreneurship improves the quality of institutions, but only in such environments with institutions of high quality where political entrepreneurship is directed towards productive activities in the first place. Conversely, political entrepreneurs in countries with low quality institutions are more likely to engage in rent-seeking activities, some of which likely to cause institutional quality to deteriorate even further. This mechanism forms the root of the socalled curse of natural resources (e.g., Boschini et al. 2007).

The interaction between institutions and entrepreneurship is not limited to political entrepreneurship. Productive market entrepreneurship can change the operating field and create new opportunities for political entrepreneurship. British institutions, for example, not only encouraged the Industrial Revolution, they adapted rapidly to the new technology and production methods introduced by market entrepreneurs. The same is true for the recent revolution in

\footnotetext{
${ }^{13}$ Veblen himself did not emphasize the individual entrepreneur as a driver of technological change (Gurkan 2005). Nevertheless, his thesis can be extended to entrepreneur-driven technological change in a rather straightforward manner.
} 
information and communications technology centered in the United States, which evolved in tandem with institutional changes pursued by politicians that aided the growth of the venture capital industry (Fenn et al. 1995, Gompers and Lerner 2004).

These examples illustrate that abiding market entrepreneurship can be complementary to altering political entrepreneurship, both increasing the scope of the other by creating new opportunities. Traditional market entrepreneurship differs from other factors of production in the sense that the marginal product does not typically diminish in the supply of the factor. Additional capital competes with and generally lowers the marginal productivity of already existing capital. The same is true for additional labor. While entrepreneurs also compete with each other, entrepreneurship is distinct as a factor of production in that other people's innovations can pave the way for one's own innovations by creating further opportunities for new ventures (Holcombe 2007). ${ }^{14}$ As we see it, such complementarity may also be true for political and business entrepreneurship. There is no guarantee that opportunities created by new reforms will be used solely for productive policy innovations. Productive market innovations may lead to destructive political innovation, especially when the broader institutional setting is less geared towards socially beneficial activity. For example, surveillance technology developed largely by entrepreneurial IT firms has been used to increase political oppression in countries such as Iran and China.

The feedback between entrepreneurship and institutions can help explain the discontinuous nature of the dynamics of economic growth. This provides one possible explanation for the phenomenon that the economies of some countries long mired in stagnation suddenly take off, propelled by a virtuous cycle of entrepreneurship and institutional change. The breaking point of stagnation can be either reforms by political entrepreneurs that create opportunity for market entrepreneurship, or technological change promoted by business entrepreneurs that in turn creates opportunity for productive political entrepreneurship. The growth and reform cycle continues as more market entrepreneurship raises the possibility for additional institutional reforms and political return, which leads to further growth and entrepreneurship.

\footnotetext{
${ }^{14}$ In this sense entrepreneurial innovation is similar to knowledge and ideas in general, which are not generally believed to be characterized by diminishing returns to scale (Arrow 1962, Romer 1986, Lucas 1988).
} 


\section{Examples from Recent History}

\subsection{Productive and Destructive Policy Entrepreneurship in Singapore and Zim- babwe}

Singapore's Lee Kuan Yew embodies an example of productive institutional entrepreneurship that dramatically increased productive business activity. Early in his life, he helped found a political party that eventually grew to be the largest in the city-state. He maintained cohesion and secured room for impressive reforms by forging political alliances in an ethnically fragmented country. From Singapore's independence in 1965 through 1990, Lee and his People's Action Party developed the unique set of pro-growth institutions in Singapore that would see the isolated and resource-poor country grow to become one of the richest in the world (Peebles and Wilson 2002). Singapore's soaring growth can be traced to both market entrepreneurship and foreign direct investment by large public firms. This success further strengthened the evolution of institutions through increased legitimacy for capitalism and created a pro-reform constituency. As growth took off, new investments and business ventures created the opportunity for additional policy entrepreneurship, which was readily provided. Singapore illustrates how one policy entrepreneur can positively change the entire incentive structure of a society.

Zimbabwe's Robert Mugabe, on the other hand, is the destructive equivalent of Lee Kuan Yew. His political entrepreneurship also changed the incentive structures of his country, although in the opposite direction (Meredith, 2002). Zimbabwe's path to wealth suffered an about-face, shifting from production to destructive rent extraction. The entrepreneur behind this transformation-Robert Mugabe-became wealthy in the transformative process while his nation suffered. As Baumol pointed out in his original theory, there is no guarantee that an entrepreneur's wealth will be auspicious for society. Indeed, Mugabe's example allows us to point to what distinguishes our expanded theory from Baumol's own. In his theory, the institutional framework of Zimbabwe led an entrepreneur to act destructively for personal gain. In ours, the originally productive institutions of Zimbabwe were altered by the policy entrepreneur Mugabe. The incentives in the country changed as a result, with destructive entrepreneurship becoming the easiest path to wealth for thousands of Zimbabweans, whose predatory behavior also destroyed some of the wealth of the country; indeed, the successful occupation of a farm requires alertness, organizational power and risk-taking. Previously productive entrepreneurs were put out of business, and many left the country altogether. Zimbabwe illu- 
strates that destructive institutional entrepreneurship can be much more powerful than destructive abiding entrepreneurship.

\subsection{Interaction of Political and Productive Entrepreneurship in China}

China's two-fold transition to a Socialist command economy and later back to one of the fastest growing countries in the world exemplifies some of the interactions between entrepreneurship and institutions. China is a particularly interesting case since entrepreneurs have also been key agents in the more recent transition from Socialist planning. The move to a fullblown Socialist regime after the Communist revolution in 1949 was a gradual process com-

pleted in 1956/57. ${ }^{15}$ Step-by-step, private enterprise was circumscribed as more and more sectors were collectivized and government involvement in management was extended. In a first move taking place between 1949 and 1952, private financial institutions were nationalized and private capital markets were shut down. The government began placing processing orders with private producers and took charge of most resource allocation. Plans for production and sales had to be approved by officials.

Entrepreneurs were still allowed to engage on the market and respond to market signals, but the institutional reforms brought about far-reaching changes in their operations. Entrepreneurial activity was reduced to a contest for winning orders and escaping controls. At the same time, the system offered ample opportunities for officials in charge of processing orders and means of production to earn rents through corruption. The consequences for private firms and the economy as a whole were highly detrimental. In 1951, the government began to strike back at these so-called "five evils": bribery of government officials, tax evasion, theft of state property, cheating on government contracts, and theft of economic information for speculative purposes. The blame was largely directed towards the private sector and resulted in an accelerated rate of collectivization and nationalization of resources.

The Communist takeover radically changed China's institutional setup, with the new institutions drastically decreasing incentives for productive entrepreneurship. Entrepreneurs were forced to expend more effort on evasive activities. The new institutions also provided fertile soil for unproductive forms of entrepreneurship. Rents could be earned by competing for bureaucratic positions that functioned as gatekeepers for licenses and government contracts.

\footnotetext{
${ }^{15}$ Our account draws on Lu (1994, ch. 4), and Lewis and Teets (2009).
} 
These changes legitimated demands for further institutional reforms. Radical Communist factions gained political power as private enterprise was blamed for the malfunctioning quasiSocialist economy. The increased power of these groups induced further changes in economic institutions.

Soon enough, a political entrepreneur came to the aid of business entrepreneurship. After the death of Mao in 1976, Deng Xiaoping rose to power in 1978 and initiated reforms that extended the scope of private enterprise. The subsequent events illustrate the endogenous relationship between entrepreneurial activities and institutions. Unlike the transformation in the Soviet Union and Eastern Europe, Deng's reforms were far from wholesale privatization (Heilman 2008). Rather, they opened small arenas for productive business entrepreneurship at first, sometimes abiding and sometimes evading. The initially small productive sector of the Chinese economy began to grow year by year through successful entrepreneurial ventures (Tsai 2006).

One example of the role of the entrepreneur in the ensuing transformation of Chinese institutions was the implementation of the practice of "contract-production-to-household", which allocated land to households on a long-term basis and allowed farmers to retain profits. This practice was officially endorsed in 1983, but had already been widely adopted in practice. The former laws that had prohibited private profits from household farming had lost all practical relevance. Another example is the policy document enforced in 1981, which allowed limited private enterprise, with severe restrictions on the maximum number of employees (two employees and five apprentices). However, these limitations did little to constrict the size of private firms, of which many grew well beyond the permitted size. By the end of 1986, an official survey showed that a large number of firms had exceeded the stipulated limits. New institutional reforms in 1987/88 later granted these firms legitimate status. Lu (1994, p. 117) concludes that "the Chinese policy makers did not pre-design the boom of the private sector in the 1980s and the relating changes in institutions. In many cases, what happened was the official adaptation to reforms initiated by private entrepreneurs."

Deng's small windows of productive entrepreneurship opened up the entire system in time. China's new productive institutions were greatly strengthened through abiding productive ventures, and have now organically evolved from exceptions to the dominant institutions of Chinese society. As incentives changed, talented individuals shifted from government em- 
ployment or Communist Party careers to private enterprise (sometimes combining the two in a unique Chinese mix). Political support for productive activity grew as a larger part of the elite began to derive its income from these institutions. While business entrepreneurs were presumably driven by a profit motive, the political class also had stronger incentives to support reform. ${ }^{16}$ Without these feedback mechanisms it is unlikely that reform would have been so far-reaching.

Daokui et al. (2006) argue that market entrepreneurs help improve institutions by starting a business venture, thereby contributing to the destruction of prevailing institutions that are unfavorable to entrepreneurship. Apart from open advocacy of reforms and the private persuasion of politicians, they mention two other strategies. The first involves a business owner who claims that he represents a special case, and that exceptions should be made for him. Once a concession has been made, additional concessions are easier to obtain, eventually adding up to a de facto change in institutions. The other strategy requires one to circumvent regulations and, once a successful enterprise has been established, argue for an ex post modification. This type of entrepreneurship has, according to the authors, changed the institutional environment not only in China but also in other rapidly growing economies such as India and Vietnam. As observed by Gilley (2002), Chinese politicians appointed at the local level frequently have a background as former (or current) entrepreneurs. ${ }^{17}$

The Chinese experience also highlights the role of productive evasive entrepreneurship as an engine for institutional change. Although many of the Chinese institutions that imposed restrictions on entrepreneurship were still in place in the mid-1970s, the political will to enforce such restrictions weakened under Deng Xiaoping, and the institutions were eventually phased out as attention waned. The risk of sanctions - and thereby the cost of evading the institutions in question-decreased significantly, enhancing productive entrepreneurial activity. This was

\footnotetext{
${ }^{16}$ While our theory accounts for the behavior of business entrepreneurs and the actions of Chinese policy entrepreneurs when the reform cycle took hold, we admittedly cannot account for Deng Xiaoping's initial reforms. This is taken as exogenous both in the Chinese case and in the case of Singapore and Lee Kuan Yew. Both Deng and Lee were in power long enough to witness the benefits of the reforms they initiated, so their behavior is at least not incongruent with welfare-maximizing entrepreneurship. But why did these leaders initiate successful policy reforms and not others? Trying to answer this question is outside the scope of this paper.

${ }^{17}$ Djankov et al. (2006) present evidence that Chinese entrepreneurs value political freedom significantly more than non-entrepreneurs. This suggests that entrepreneurs might be an important force in bringing about change in political institutions in the future as well.
} 
a cumulative process by which the costs of evading regulation fell to a level where the institutions had lost all practical relevance, and in the end they were formally abolished.

The Chinese experience also indicates that institutions can affect not only the direction of entrepreneurship, but also its total supply. It would be difficult to argue that the torrent of entrepreneurial business activity that has been unleashed during the last few years, transforming not only the Chinese but also the world economy, does not represent an increase over previous levels. Even when taking into account rent seeking activity, evasion and political entrepreneurship within the Communist party, China doubtlessly has more entrepreneurship in its current institutional framework than under pure Communism.

\subsection{A Vicious Cycle of Unproductive Entrepreneurship in Post-Transition Russia}

According to Åslund, Boone and Johnson (2002), post-Soviet Russia is locked in an "underreform trap". Institutions that reward rent seeking more than productive activities dominate the economy, and political influence from the Russian private sector can often be traced to oligarchs (Guriev and Rachinsky 2005). This group consists of people from the former Soviet nomenclature who seized power over the companies they managed after the fall of the Soviet Union. The oligarchs took advantage of the huge arbitrage opportunities created by partial reforms and the co-existence of regulated and quasi-market prices during the Gorbachev era.

There is no denying that rising from virtually nothing to amassing billions in the era of reform required entrepreneurial talent. However, most activity was non-productive; wealth was generated by taking control over firms or plundering them rather than creating new value. Kalantaridis and Labrianidis (2004) argue that the most important group of entrepreneurs during the transition period were "directors of the Socialist Era" who were "individuals in positions of authority during the Socialist Era, who adapted successfully to change". While the allocation of entrepreneurs from a Socialist system to a free market system may seem dramatic, the move was modest seen through the framework of this paper. Largely unproductive entrepreneurship under the low-quality Soviet institutions moved to largely unproductive entrepreneurship in the only marginally less distortive institutions of the transition era.

Unproductive entrepreneurship in Russia proved self-reinforcing, in at least two ways. For one, the legitimacy of free market capitalism was deeply damaged by the initial era of unpro- 
ductive entrepreneurship. Second, the current oligarchs continue to use their political power to defend the current system, exemplified by their takeover of the Russian Union of Industrialists and Entrepreneurs. Slinko et al. (2005) underscore the negative effect of the establishment's political influence, finding that large firms with high political stakes can prevent entry of new firms. Aidis et al. (2008) show that Russia has less business entrepreneurship than other transition countries, and that Russian institutions provide advantages to insiders over new ventures. In comparison to other transition economies, Russian entrepreneurs face more corruption, higher official and unofficial start-up costs, higher tax rates, more bureaucracy, and weaker protection of property rights (Åslund et al. 2002). Contrasting Russia's current trap with the virtuous cycle of institutional reform and entrepreneurship in China makes for an interesting task, and may offer hints about how to escape a bad equilibrium.

\subsection{The Market Entrepreneur as Political Entrepreneur in Italy}

Italian Prime Minister Silvio Berlusconi represents a conspicuous example of an individual who acted both as a business entrepreneur and as a political entrepreneur, profoundly affecting institutions in both roles. Circumventing laws that only allowed Italian public television to broadcast nationally, he set up a system of local stations that broadcast the same programs simultaneously. In doing so, Berlusconi essentially created Italy's first private national television network. Italian public television capitulated in due course, allowing free competition over the airwaves. This is a striking example of how evasive entrepreneurship can alter institutions. ${ }^{18}$ On the one hand, the reform shows a form of productive entrepreneurship, simply because there was a demand for private entertainment television in Italy. On the other hand, Berlusconi's political exploitation of his private control over television networks has been deemed socially destructive by some observers, which complicates matters. Throughout his business career, Berlusconi has not shied away from using his political connection to extract rents and favors for himself. His case illustrates that political entrepreneurship can be both productive and unproductive at the same time.

The story does not end there, however. Aided by his media empire, Berlusconi ventured into large-scale political entrepreneurship, shattering the previous Italian party system. The political party he founded grew to be the largest one in the most recent Italian elections. By changing the election laws and arduously forming new alliances, he transformed Italy into what

\footnotetext{
${ }^{18}$ Berlusconi's evasive entrepreneurship in media and other business arenas are widely suspected to have crossed the line to breaches of the law.
} 
resembles a two-party system. Berlusconi used his political power to dramatically alter Italian formal institutions in several more important dimensions, largely to aid his own private ventures and to shield himself from legal action.

Needless to say, Berlusconi is not only a mover of certain Italian institutions, but also a product of the country's broader institutional setting. More than other western countries, Italy combines rigid regulations with endemic evasion. Berlusconi's dual involvement in politics and business was aided by his early political connections, which are common for successful businessmen in contemporary Italy. While posterity will have to determine whether Berlusconi's political entrepreneurship was largely productive or destructive, his case illustrates without a doubt that entrepreneurs are not only influenced by the institutional setting, but can shape institutions themselves.

\subsection{Welfare State Entrepreneurship in Sweden}

The Swedish example illustrates several venues of interaction between institutions and entrepreneurship. Unlike other examples, high level of wealth produced by entrepreneurship did not initially lead to a virtuous cycle of further institutional improvements, instead funding a welfare state that was detrimental to market entrepreneurship. In addition, and perhaps partially in lieu of private sector innovativeness and talent, Sweden offered a well-functioning political system amenable to political entrepreneurship. Because of the responsiveness of political entrepreneurship to diminished market entrepreneurship, the institutional environment was ultimately reformed to become more favorable for market entrepreneurs.

Between 1870 and 1970 Sweden enjoyed a fertile institutional climate for market entrepreneurship, which resulted in the second highest growth rate in the world over that century (Maddison 1982). Based on this wealth, Social-Democratic Sweden implemented policies in the post-war period that eroded the accumulation of private wealth, private ownership of the business sector and, ultimately, productive business entrepreneurship. As Henrekson and Jakobsson (2001) show, tax and industrial policies moved the economy towards larger business entities and institutional rather than individual ownership. Tax policy created a large wedge between wealth accumulation at the corporate and individual levels, thereby benefiting large incumbent firms over new entrants and individual entrepreneurs. ${ }^{19}$ Export firms, often initially

\footnotetext{
${ }^{19}$ The actual effects of these policies on such variables as the size distribution of firms and employment and the industry distribution of production and employment are documented in Davis and Henrekson (1997).
} 
founded by individual entrepreneurs, had by this time grown into large public companies, providing the economic base of the welfare state. The major incumbent owners managed to retain control despite this large wedge through a growing disparity between control rights and cash-flow rights. A number of devices were used to achieve this, the most important of which were dual-class shares and pyramiding with tax-favored closed-end investment funds as the prime control vehicle. By the late 1980s, it became apparent that higher taxes and such intrusions in market mechanisms had taken a heavy toll on economic growth and productive business entrepreneurship. Virtually all the fifty largest firms in Sweden in the year 2000 were founded before 1970 (Henrekson 2005). The lack of productive business entrepreneurship has been called "the Achilles heel of the Swedish welfare state" (Högfeldt 2005).

A balanced history of the welfare state should account for its successes and failures at one and the same time. As productive business entrepreneurship was hampered in Sweden, a corresponding increase in unproductive entrepreneurship did not occur, in contrast to what the Baumol (1990) framework would suggest. Sweden's political institutions worked reasonably well throughout the era, with little evidence of rent seeking. One interpretation could take up the stifling, long-run effects of Social Democratic institutions on the total supply of entrepreneurship, which led to a decrease in productive entrepreneurship but no corresponding increase in unproductive/destructive entrepreneurship. ${ }^{20}$ Aside from a decrease in total entrepreneurship, political entrepreneurship also rose. However, in contrast to what Baumol's theory would predict, this political entrepreneurship was not unproductive. Rather, Sweden channeled much of its innovative energy of this period into welfare state entrepreneurship, pioneering policies that were later adopted by other countries (Pontusson 2005). This includes the health care system, social insurance, active labor market programs and the care of children and the elderly. The political system was attentive to the changing needs of industry (Steinmo 2010). In addition, there was a myriad of policies at the municipal level aimed at producing local public goods. Much of the country's talent that would have otherwise gone to the private sector was drawn into the public sector. Talented individuals, including Nobel laureates, were attracted to the creation of the new system and helped design and improve the welfare state.

A public sector as large and intrusive as the Swedish one would not have functioned without a focus on mitigating incentive problems as much as possible (Freeman et al. 1997, Lindert

\footnotetext{
${ }^{20}$ However, evasive entrepreneurship increased somewhat, especially with the aim of evading high taxes and onerous labor market regulations.
} 
2004). In order to ensure high labor force participation despite punitive tax levels, participating in the labor force became a requirement for access to many highly subsidized services and transfers (Lindbeck 1982). Furthermore, women's participation was encouraged by subsidizing consumption complementary to work. The system was responsive above all. Government programs were continuously reformed in order to maintain economic performance. Social insurance programs whose generosity was being exploited were often quickly reformed. In many ways the Swedish system outperformed others, not necessarily in an absolute sense, but compared to the likely outcome in other countries had they ventured this far in expanding the welfare state. Continental European countries such as France and Belgium with lower taxes have fewer hours worked than Sweden. Recent research on taxes and hours worked in Europe has identified Sweden and other similar Scandinavian countries as positive "outliers" in the relationship between taxation and work, a fact attributed to the unique design of public spending programs aimed at mitigating the problems caused by the high levels of taxation (Rogerson 2007).

The high degree of productive political entrepreneurship in the Swedish system became most apparent as the problems of the welfare state grew in its mature phase. The country responded by rolling back some of the most far-reaching reform programs in history (Bergh and Erlingsson 2009, Steinmo 2010). This included a fundamental tax reform, financial deregulation, restructuring of macroeconomic policy, reduction of the generosity of social insurance programs, transformation of the pension system, and modification of labor market policies. While we do not want to push the story too hard-many problems remain in the Swedish economy, in particular a high level of non-employment in marginal groups-Sweden's adaptive responsiveness has contained a high degree of productive political entrepreneurship. As a result, room for business entrepreneurship has also increased. Most of the underlying principles of the welfare state were maintained, but the system became much more favorable for productive business entrepreneurship.

This showcases another aspect of the interaction between institutions and entrepreneurship. When the institutions that guide politics and political entrepreneurship are of sufficient quality, the political system will have a highly elastic supply of productive policy entrepreneurship. In such an environment, the institutions that regulate market activity are unlikely to be allowed to evolve in too detrimental a fashion. The welfare state institutions were bounded by 
their impact on the supply of business entrepreneurship, and ultimately reformed in order to stimulate the supply of new rapidly growing firms again.

\section{Conclusion}

This paper expands on the framework introduced by Baumol (1990). Entrepreneurship is not only shaped by institutions, it also influences institutions in turn. On the one hand, entrepreneurs choose how to employ their entrepreneurial talent depending on the relevant incentive structure as determined by the pertinent institutions. In this way, institutions fundamentally determine the distribution across productive, unproductive and destructive entrepreneurial activities. On the other hand, entrepreneurs respond actively to the environment they face, which tends to affect institutions.

Since these types of activities all involve a measure of innovation, politicians cannot fully anticipate these effects when designing institutions. Our analysis highlights the need to view the formation of institutions as an adaptive process. Politicians cannot design optimal institutions once and for all; unpredictable entrepreneurial responses to these institutions will force them to respond by continually changing and amending the institutional environment. Research on the political economy of entrepreneurship cannot be restricted to analyzing how institutions affect the level and type of entrepreneurial activity. It is also necessary to consider how entrepreneurial activities affect institutions and thereby the prospects for long-term growth. Institutional changes aimed at promoting entrepreneurship must always be evaluated with respect to what kind of entrepreneurship is promoted. A tax hike may not only deter productive entrepreneurs, but also encourage unproductive entrepreneurship.

Finally, it is worth asking whether altering political entrepreneurship can change the allocation of political entrepreneurship. Most political entrepreneurship is too insignificant to palpably change the broader incentive structures. The allocation and lucrativeness of policy entrepreneurship itself changes, however, either through comprehensive acts of reform by single policy entrepreneurs or through slow incremental change. In terms of contemporary protracted reform, various reform-minded policy entrepreneurs are slowly bringing the old statist system to an end. An example of more radical change is the promise to stifle lobbying in the United States (not yet realized at the time of writing). Such an act of large-scale policy entrepreneurship could change institutions enough to alter the allocation of multitudes of smaller 
scale policy entrepreneurship, presumably reducing unproductive political entrepreneurship. There would be positive multipliers associated with this reform due to the mechanisms we have pointed to. Not only would unproductive lobbying be reduced, in addition some of the entrepreneurial resources could be redirected to business entrepreneurship or more productive political entrepreneurship. Perhaps some of these activities would someday in turn lead to additional institutional improvements. The gains from channeling entrepreneurship into productive use is thus larger than a narrow look at the market activity would suggest, and larger still due to (by its nature) hard-to-anticipate improvements in institutions. 


\section{References}

Acemoglu, Daron (1995), "Reward Structures and the Allocation of Talent." European Economic Review, 39(1), 17-33.

Acemoglu, Daron, and James A. Robinson (2006), "Persistence of Power, Elites and Institutions." American Economic Review, 98(1), 267-293.

Acemoglu, Daron, Simon Johnson and James A. Robinson (2005), "Institutions as the Fundamental Cause of Long-run Growth." In Philippe Aghion, and Steven Durlauf, eds., Handbook of Economic Growth. Amsterdam: Elsevier, 385-472.

Acs, Zoltan J., and Ronnie J. Phillips, (2002), "Entrepreneurship and Philanthropy in American Capitalism." Small Business Economics, 19(3), 189-204.

Aidis, Ruta, Saul Estrin and Tomasz Mickiewicz (2008), "Institutions and Entrepreneurship Development in Russia: A Comparative Perspective." Journal of Business Venturing, 23(6), 656-672.

Arrow, Kenneth J. (1962), "The Economic Implications of Learning by Doing." Review of Economic Studies, 29(3), 155-173.

Åslund, Anders, Peter Bonne and Simon Johnson (2002), "Escaping the Under-Reform Trap." IMF Staff Papers 48(1), 88-108.

Asoni, Andrea, and Tino Sanandaji (2009), "Taxation and the Quality and Quantity of Entrepreneurship.” IFN Working Paper No. 813, Research Institute of Industrial Economics, Stockholm.

Battilana, Julie (2006), "Agency and Institutions: The Enabling Role of Individuals' Social Position." Organization, 13(5), 653-676.

Battilana, Julie, Bernard Leca, and Eva Boxenbaum (2009), "How Actors Change Institutions: Towards a Theory of Institutional Entrepreneurship." Academy of Management Annals, 3, 65-107.

Baumol, William J. (1990), “Entrepreneurship: Productive, Unproductive, and Destructive.” Journal of Political Economy, 98(5), 893-921.

Baumol, William J. (2010), The Microtheory of Innovative Entrepreneurship. Princeton, NJ: Princeton University Press.

Becker, Gary S., and Kevin M. Murphy (2000), Social Economics: Market Behavior in a Social Environment, Boston, MA: Harvard University Press.

Bergh, Andreas and Gissur Ó. Erlingsson (2009), "Liberalization without Retrenchment: Understanding the Consensus on Swedish Welfare State Reforms." Scandinavian Political Studies, 32(1), 7193.

Boettke, Peter J., and Christopher J. Coyne (2003), "Entrepreneurship and Development: Cause or Consequence?" Advances in Austrian Economics, 6, 67-87.

Boettke, Peter J., and Christopher J. Coyne (2009), "Context Matters: Institutions and Entrepreneurship." Foundations and Trends in Entrepreneurship, 5(3), 135-209.

Boettke, Peter J. and Peter T. Leeson (2009), "Two-Tiered Entrepreneurship and Economic Development." International Review of Law and Economics, 29(3), 252-259.

Boschini, Anne, Jan Pettersson and Jesper Roine (2007), "Resource Curse or Not: A Question of Appropriability." Scandinavian Journal of Economics, 109(3), 593-617.

Buchanan, James M. (1980), ”Rent Seeking and Profit Seeking.” In James M. Buchanan, and Gordon Tollison, eds., Toward a Theory of the Rent-Seeking Society. College Station, TX: Texas A\&M University Press, 3-15.

Calomiris, Charles (2009), "Financial Innovation, Regulation, and Reform.” The Cato Journal, 29(1), 65-91.

Caplan, Bryan (2007), The Myth of the Rational Voter: Why Democracies Choose Bad Policies. Princeton, NJ: Princeton University Press.

Chong, Alberto, and César Calderón (2000), "Causality and Feedback between Institutional Measures and Economic Growth." Economics and Politics, 12(1), 69-82.

Calomiris, Charles (2009), "The Subprime Turmoil: What's Old, What's New, and What's Next," Journal of Structured Finance, 15(1), 6-52. 
Coyne, Christopher J., and Peter T. Leeson (2004), "The Plight of Underdeveloped Countries." Cato Journal, 24(3), 235-249.

Dahl, Robert (1961), Who Governs? New Haven, CT: Yale University Press.

Daokui Li, David, Junxin Feng and Hongping Jiang (2006), "Institutional Entrepreneurs." American Economic Review, 96(2), 358-362.

Davis, Steven J., and Magnus Henrekson (1997), "Industrial Policy, Employer Size and Economic Performance in Sweden." In Richard B. Freeman, Robert Topel and Birgitta Swedenborg, eds., The Welfare State in Transition. Chicago: University of Chicago Press, 353-397.

DiLorenzo, Thomas (1988), "Competition and Political Entrepreneurship." Review of Austrian Economics, 2(1), 59-71.

DiMaggio, Paul J. (1998), “Interest and Agency in Institutional Theory.” In Lynne Zucker, ed., Institutional Patterns and Organizations. Cambridge, MA: Ballinger, 3-22.

Djankov, Simeon, Yingyi Qian, Gérard Roland and Ekaterina Zhuravskaya (2006), "Entrepreneurship in China and Russia Compared." Journal of the European Economic Association, 4(2/3), 352-365.

Douhan, Robin, and Magnus Henrekson (2010), "Entrepreneurship and Second-best Institutions: Going Beyond Baumol's Typology." Journal of Evolutionary Economics, 20(4), 629-643.

Fenn, George W., Nellie Liang, N. and Stephen Prowse (1995), The Economics of the Private Equity Market. Washington, D.C.: Board of Governors of the Federal Reserve System.

Freeman, Richard B., Robert Topel and Birgitta Swedenborg, eds. (1997), The Welfare State in Transition. Chicago: University of Chicago Press.

Gaglio, Connie Marie, and Jerome A. Katz (2001), "The Psychological Basis of Opportunity Identification: Entrepreneurial Alertness." Small Business Economics, 16(2), 95-111.

Gilley, Bruce (2002), "Entrepreneurs and Politics in Rural China." In Victoria E. Bonnell and Thomas B. Gold, eds., The New Entrepreneurs of Europe and Asia. New York and London: M.E. Sharpe, 66-82.

Glaeser, Edward. L. (2005), "Paternalism and Psychology.” NBER Working Paper No. 11789.

Gompers, Paul, and Josh Lerner (2004), The Venture Capital Cycle, 2nd ed.. Cambridge, MA: MIT Press.

Guriev, Sergei, and Andrei Rachinsky (2005), "The Role of Oligarchs in Russian Capitalism.” Journal of Economic Perspectives, 19(1), 131-150.

Gurkan, Ceyhun (2005), “A Comparison of Veblen and Schumpeter on Technology.” STPS Working Paper No. 509.

Hall, Robert E., and Charles I. Jones (1999), "Why Do Some Countries Produce So Much More Output per Worker than Others?" Quarterly Journal of Economics, 114(1), 83-116.

Heilmann, Sebastian (2008), "From Local Experiments to National Policy: The Origins of China's Distinctive Policy Process." China Journal, 59, 1-30.

Henrekson, Magnus (2005), "Entrepreneurship_A Weak Link in the Welfare State?" Industrial and Corporate Change, 14(3), 437-467.

Henrekson, Magnus, and Ulf Jakobsson (2001), "Where Schumpeter Was nearly Right - the Swedish Model and Capitalism, Socialism and Democracy." Journal of Evolutionary Economics, 11(3), 331-358.

Henrekson, Magnus, and Tino Sanadaji (2010), "Entrepreneurship and the Theory of Taxation." Small Business Economics, forthcoming.

Högfeldt, Peter (2005), "The History and Politics of Corporate Ownership in Sweden.” In Randall K. Morck, ed., A History of Corporate Governance around the World: Family Business Groups to Professional Managers. Chicago: University of Chicago Press, 517-579.

Holcombe, Randall G. (2007), Entrepreneurship and Economic Progress, New York: Routledge.

Hwang, Hokyu, and Walter W. Powell (2005), "Institutions and Entrepreneurship." In Sharon A. Alvarez, Rajshree Agarwal and Olav Sorenson, eds., Handbook of Entrepreneurship Research. Boston and Dordrecht: Kluwer, 179-210. 
Kalantaridis, Christos, and Lois Labrianidis (2004), "Rural Entrepreneurs in Russia and the Ukraine: Origins, Motivations, and Institutional Change." Journal of Economic Issues, 38(3), 659-682.

Kasper,Wolfgang and Manfred E. Streit (1998) Institutional Economics. Cheltenham, UK, and Northampton, MA: Edward Elgar.

Kirzner, Israel M. (1973), Competition and Entrepreneurship. Chicago and London: University of Chicago Press.

Kirzner, Israel M. (1992), The Meaning of the Market Process: Essays in the Development of Modern Austrian Economics. New York: Routledge.

Kirzner, Israel M. (2009), “The Alert and Creative Entrepreneur: A Clarification.” Small Business Economics, 32(2), 145-152.

Knight, Frank H. (1921), Risk, Uncertainty and Profit, New York: Houghton Mifflin.

Krueger, Anne O. (1974), "The Political Economy of the Rent-Seeking Society." American Economic Review, 64(3), 291-303.

La Porta, Rafael, Florencio Lopez-de-Silanes, Andrei Shleifer and Robert Vishny (1999), "The Quality of Government." Journal of Law, Economics and Organization, 15(1), 222-279.

Lewis, Orion, and Jessica Teets (2009) A China Model? Understanding the Evolution of a "Socialist Market Economy". Looking Glass Report. Stockholm: Glasshouse Forum.

Lindbeck, Assar (1982), "Tax Effects versus Budget Effects on Labor Supply.” Economic Inquiry, 20(3), 473-489.

Lindert, Peter H. (2004), Growing Public: Volume 1, The Story: Social Spending and Economic Growth since the Eighteenth Century. Cambridge and New York: Cambridge University Press.

Lu, Ching (1994), Entrepreneurship in Suppressed Markets: Private-Sector Experience in China. New York: Garland.

Lucas, Robert E. (1988), "On the Mechanics of Economic Development." Journal of Monetary Economics, 22(1), 3-42.

Maddison, Angus (1982), Phases of Capitalist Development. Oxford: Oxford University Press.

McClelland, David C. (1961), The Achieving Society. Princeton: Van Nostrand.

Meredith, Martin (2002), Mugabe: Power and Plunder in Zimbabwe. London: Perseus Press.

Murphy, Kevin M., Andrei Shleifer and Robert W. Vishny (1991), "The Allocation of Talent: Implication for Growth." Quarterly Journal of Economics, 106(2), 503-530.

North, Douglass C. (1990), Institutions, Institutional Change and Economic Performance. Cambridge: Cambridge University Press.

North, Douglass C., and Barry R. Weingast (1989), "Constitutions and Commitment: Evolution of Institutions Governing Public Choice in Seventeenth Century England." Journal of Economic History, 49(4), 803-832.

Olson, Mancur (1965), The Logic of Collective Action: Public Goods and the Theory of Groups. Cambridge, MA: Harvard University Press.

Parker, Simon C. (2004), The Economics of Self-Employment and Entrepreneurship. Cambridge: Cambridge University Press.

Peebles, Gavin, and Peter Wilson (2002), Economic Growth and Development in Singapore: Past and Future. Cheltenham, UK, and Northampton, MA: Edward Elgar.

Persson, Torsten, and Guido Tabellini (2004), "Constitutions and Economic Policy." Journal of Economic Perspectives, 18(1), 75-98.

Persson, Torsten, and Guido Tabellini (2006), "Electoral Systems and Economic Policy." In Barry R. Weingast and Donald A. Wittman, eds., Handbook of Political Economy. New York: Oxford University Press, 723-738.

Polsby, Nelson (1984), Political Innovation in America. New Haven, CT: Yale University Press.

Pontusson, Jonas (2005), Inequality and Prosperity: Social Europe versus Liberal America. Ithaka, NY: Cornell University Press. 
Rauch, Andreas, and Michael Frese (2000), "Psychological Approaches to Entrepreneurial Success. A General Model and an Overview of Findings." In Cary L. Cooper and Ivan T. Robertson, eds., International Review of Industrial and Organizational Psychology, 13, 101-142.

Rodrik, Dani (2008), “Second-best Institutions.” American Economic Review, 98(2), 100-104.

Rodrik, Dani, Arvind Subramanian and Francesco Trebbi (2004), "Institutions Rule: The Primacy of Institutions over Geography and Integration in Economic Development." Journal of Economic Growth, 9(2), 131-165.

Rogerson, Richard (2007), “Taxation and Market Work: Is Scandinavia an Outlier?" Economic Theo$r y, 32(1), 59-85$.

Romer, Paul M. (1986), "Increasing Returns and Long-Run Growth.” Journal of Political Economy, 94(5), 1002-1037.

Schneider, Mark, Paul Teske and Michael Minton (1995), Public Entrepreneurs: Agents for Change in American Government. Princeton, NJ: Princeton University Press.

Schumpeter, Joseph A. (1934), The Theory of Economic Development, Cambridge, MA: Harvard University Press.

Scott, Richard W. (1995), Institutions and Organizations. Thousand Oaks, CA: Sage.

Scott, Richard. W. (2004), "Institutional Theory: Contributing to a Theoretical Research Programme." In Ken G. Smith and Michael A. Hitt, eds., Great Minds in Management: The Process of Theory Development. Oxford: Oxford University Press, 460-485.

Slinko, Irina, Evgeny Yakovlev and Ekaterina Zhuravskaya (2005), "Law for Sale: Evidence from Russia." American Law and Economics Review, 7(1), 284-318.

Sobel, Russell S. (2008), "Testing Baumol: Institutional Quality and the Productivity of Entrepreneurship.” Journal of Business Venturing, 23(6), 641-655.

Steinmo, Sven H. (2010), The Evolution of Modern States: Sweden, Japan and the United States. Cambridge: Cambridge University Press.

Strömberg, David (2004) “Radio's Impact on Public Spending.” Quarterly Journal of Economics, 119(1), 189-221.

Swedberg, Richard (2000), Entrepreneurship: The Social Science View. Oxford: Oxford University Press.

Tsai, Kellee (2006) "Informal Adaptive Institutions and Endogenous Institutional Change in China." World Politics, 59(1), 116-141.

Van der Steen, Marianne and John Groenewegen (2009), "Policy Entrepreneurship: Empirical Inquiry into Policy Agents and Institutional Structures." Journal of Innovation Economics, 2(4), 41-61.

Walker, Donald (1977), “Thorstein Veblen's Economic System.” Economic Inquiry, 15(2), 217-222.

Wagner, Richard E. (1966), "Pressure Groups and Political Entrepreneurs: A Review Essay." Public Choice, 1(1), 161-170.

Ward, Thomas B. (2004), "Cognition, Creativity and Entrepreneurship." Journal of Business Venturing, 19(2), 173-188.

Weber, Max (2001 [1905]), The Protestant Ethic and the Spirit of Capitalism. London and New York: Routledge.

Yu, Tony Fu-Lai (2001), “An Entrepreneurial Perspective of Institutional Change.” Constitutional Political Economy, 12(3), 217-236. 